\title{
RESULTS OF ARCHAEO-GEOPHYSICAL METHODS ON ALKHANTEPE ARCHEOLOGICAL MONUMENT (AZERBAIJAN TERRITORY)
}

\author{
Safarov R.T. ${ }^{1}$, Akhundov T.I. ${ }^{2}$, Zamanova A.H. ${ }^{\text {, }}$, Aliyev Ch.S. ${ }^{1}$, \\ Sharifova A.T. ${ }^{1}$, Abdullayev A.N. ${ }^{2}$, Bagirli R.J. ${ }^{1}$ \\ ${ }^{1}$ Geology and Geophysics Institute, Azerbaijan National Academy of Science \\ 119, H. Javid Ave., Baku, Azerbaijan, AZ1143: rafiqsafarov@gmail.com \\ 2Institute of Archaeology and Ethnography, Azerbaijan National Academy of Sciences \\ 115, H. Javid Ave., Baku, Azerbaijan, AZ1073: tufan_akhundov@mail.ru
}

Keywords; Archeogeophysical methods, Alkhantepe, preventive archeology, gamma-ray surveying
Summary. Studying of archaeological sites in the fields of oil and gas pipeline routes, buildings and oil terminals is very important in Azerbaijan. The application of geophysical methods is based on the preliminary detection and investigation of important archeological objects that can be damaged by oil and gas pipelines, oil and gas fields, and construction sites. The application of these methods in our country can extend search opportunities for archaeologists, on the other hand, it could help to take into account the existing archeological monuments in the area and suggest possible adjustments for the planning stage of the industrial operations (such as oil and gas pipelines, oil and gas terminals, oil wells, etc.) and help to take preventive measures. A series of geophysical investigations have been tested in the Alkhantepe archeological zone of Azerbaijan for the purpose of developing the method and technology for the application of geophysics of small depths in the discovery and initial investigation of archaeological monuments. The sensitivity of the archaeological methods used to detect various types of objects was taken into consideration and the reliability of the results was examined on the Alkhantepe archaeological monument and the threedimensional space and time models of the archeological object were compiled. To identify the topology of the area high-precision surveying has been applied to the area as well as high-precision gravitational field measurements were performed for determination of possible archaeological sites (cavities, fractures, etc.), natural radio-based background of the area and detection of abnormal zones associated with it were performed with pedestrian gamma-planning method.

(C) 2019 Earth Science Division, Azerbaijan National Academy of Sciences. All rights reserved.

\section{Introduction}

Geophysical investigations allow getting the initial information about archeological monuments, their area of coverage and significance. In archeology geophysical methods primarily can be used for search and discovery of important archeological objects and for preventive measures. Latter have led to a new direction called "Preventive Archeology", which gives very good efficiency in the preparation of preventive measures (Clark, 1990; Мартынов, Шер, 1990).

The application of geophysical methods is based on the preliminary detection and investigation of important archeological objects that can be damaged by oil and gas pipelines, oil and gas fields, and construction sites.

The study of archaeological sites in the fields of oil and gas pipeline routes, buildings and oil termi- nals is very important in Azerbaijan. The application of these methods in our country can extend search opportunities for archaeologists, on the other hand, it could help to take into account the existing archeological monuments in the area and suggest possible adjustments for the planning stage of the industrial operations (such as oil and gas pipelines, oil and gas terminals, oil wells, etc.) and help to take preventive measures.

\section{Area of investigation}

A number of geophysical methods have been tested in Mughan archeological field in Azerbaijan to assess the sensitivity of geophysical methods in the discovery and initial investigation of archaeological monuments. The sensitivity of the archeogeophysical methods used to detect various types of 
objects was taken into consideration and the reliability of the results was verified on the Alkhantepe archaeological monument and their three-dimensional space and time models have been constructed. The research was carried out with the support of the State Oil Foundation of the Azerbaijan Republic (04.01.2018-04.01.2019).

The sensitivity of applied geophysical methods depends on geological and ecological environment, the type and character of the archeological monument. Therefore known Alkhantepe archeological field has been selected as a base in order to perform tests of geophysical methods (Figure 1). The monument is located about $4 \mathrm{~km}$ to the north of the village of Uchtepe, Jalilabad region.

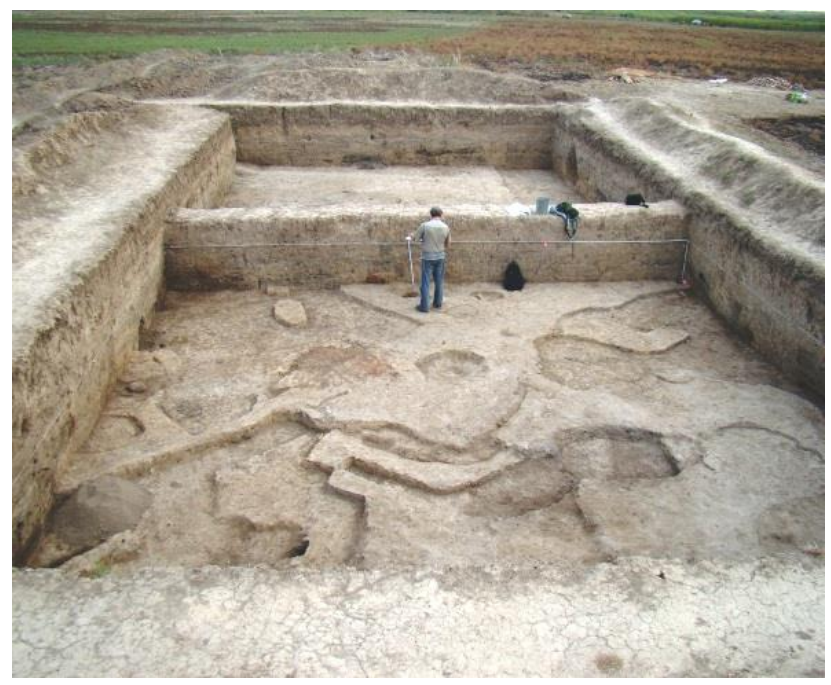

Figure 1. The view of the Alkhantepe excavation area

While the research area has a broad coverage with rich cultural history, it is located below the modern level of alluvial plain. Therefore it is covered with alluvial sediments and does not show any signs of existence on the surface. This feature of the archeological field creates ideal conditions to test the geophysical methods in order to develop necessary methodology and techniques to discover and investigate of archaeological monuments.

\section{Archeological view of the research area}

South-eastern region of Azerbaijan is divided into mountainous and lowland parts. Lowland part consists of Mughan plain situated in the north of the region and Lankaran lowland which is located between Talysh Mountains and Caspian Sea. The object of our research, the settlement Alkhantepe is on the territory of Mughan plain. The results of archaeological research of the revealed monuments and the analysis showed the following picture of settling in the region.
The traces of early inhabitants in the mountainous part of south-eastern Azerbaijan related to 5th millennium B.C. were revealed on the territory of Lerik district in the Buzeyir cave (Cəfərov, 2012). But we have no certification of settling in this region for the later long period of time.

The next settling in the lowland part of the region began in the 5th mil.B.C. and from time to time continued up to now spreading to all areas. At that period of the time tribes and states with different cultures replaced one another and inhabited the areas in accordance with their economic needs.

In the 5th mil. B.C. the tribes known as "Mughan Neoliths" have settled in Mughan plain and mainly on the territory of modern Jalilabad district. Their traces are kept up to our days in more than 20 monuments. The archaeological research was held only on two of them - Alikomektepe and Polutepe which are situated on the territory of Uchtepe village (Mirzəzadə, 2016).

There are traces of Leylatepe tribes in this region which replaced "Mughan Neoliths" tribes in the second half of the IV mil. B.C. At that time the traces of settling embrace the majority of parts of the region, the lowlands as well as the mountainous ones. One of these parts is our object of research the settlement Alkhantepe (Ахундов, 2014; Akhundov, 2018).

The next settling in south-eastern Azerbaijan replacing Leylatepe tribes and relating to the III mil.B.C. belongs to the bearers of Kur-Araxes culture. Their traces are observed in different parts of the region. But in the meanwhile the reconnoitering excavation was held only on the settlement Misharchay-I which is situated in the east of Jalilabad city, on the crossway of Misharchay and BakuAstara road (Махмудов, 2008).

We cannot show any common culture characteristic to this region in the second half of the III mln.B.C. and the first half of the III mln.B.C. At that time, the tribes belonging to different cultures mainly cattle-breaders were living here. They are revealed and observed both in the tumuli and in the remains of settlements, belonging to tribes preceding them. The only known settlement of this period was registered in Jalilabad district on the territory of Jafarkhanly village (Axundov, 2009).

In the second half of the II mln.B.C. - first half of the I mln.B.C. in the south-eastern Azerbaijan there was revealed a number of specific culture traces known as "Talysh-Mughan" culture. They appeared as "stone boxes" in mountainous parts and as tumuli in lowland areas.

Thus as we pointed it out, in the south-eastern Azerbaijan, different tribes and states replaced one another, got mixed, settled on this territory, lived 
here and left their traces. The researches and the majority of results gave the certifications which show that the most part of traces for a long time of millenniums are beyond the modern earth surface and are not observed visually. The cause of it are geomorphological processes. Traditional archaeological methods are not enough to efficiently reveal these monuments. It is necessary to use different approaches and apply new techniques and geophysical methods.

\section{Research methods}

High-precision leveling and gravity measurements were performed in order to determine possible archaeological sites (cavities, fractures, etc.) of Alkhantepe zone. Natural background radioactivity of the area and associated anomalies were detected by the pedestrian gamma-ray surveying.

\section{High-precision leveling}

High-precision leveling was performed in order to study the relief features of Alkhantepe archeological zone. Measurements were performed by the high-precision "AFL-320", produced by Pentax and GPS. Nine profiles were selected to carry out highprecision leveling measurements. Figure 2 illustrates the location of measured points on each profile.

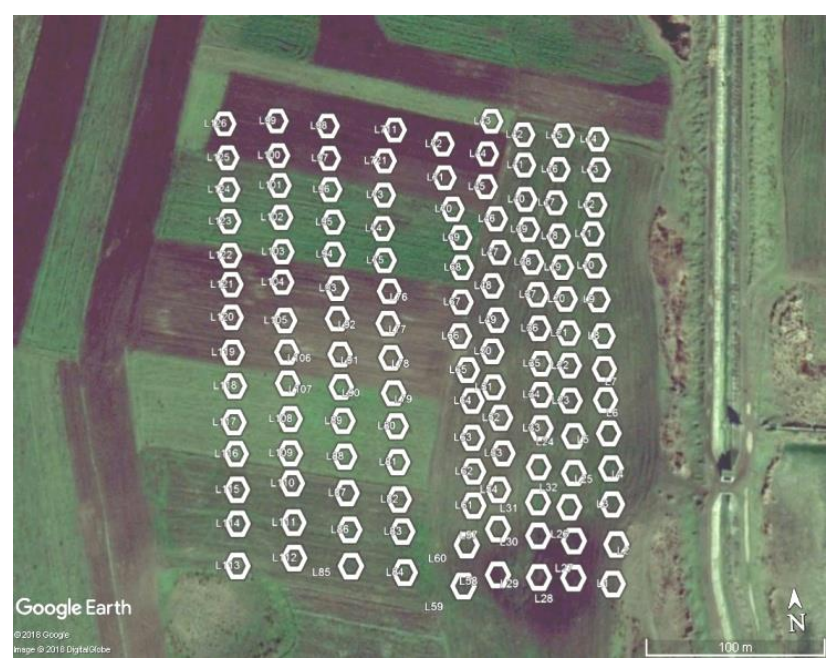

Figure 2. Leveling and gravity measurement points on the profiles in Alkhantepe area

High-precision leveling measurements were carried out on stationary bench marks. Point L1 has been selected as the starting point for measurements. The total length of the profiles is $2.7 \mathrm{~km}(65 \mathrm{pt})$. The difference between the starting points is $3.216 \mathrm{~m}$. Discrepancy of measurement was $4 \mathrm{~m}$. Acceptable error $A$ was $\pm 3 \sqrt{L} \mathrm{~mm}=18 \mathrm{~mm}$, where $L$ is the average length of one step.

\section{High-precision gravity measurements}

High precision gravity measurements were performed in order to identify possible buried archeological objects, gaps, fractures, etc. The gravity measurements were carried out on 9 parallel profiles striking from south-north and all gravity measurements were tied to the fundamental reference points. The measurements step was $20-25 \mathrm{~m}$. Bouguer anomalies were calculated using the density of intermediate layer $\left(2.67 \mathrm{~g} / \mathrm{cm}^{3}\right)$. Gravity measurements were performed with GNU-K2 gravimeter. Temperature changes, the Earth's tides and the surrounding relief features, as well as the non-linearity of the gravimeter system were taken into account during gravity data processing. Measurement of gravity difference between two neighbor points $\mathrm{A}$ and $\mathrm{B}$ is done with a simple loop scheme $(\mathrm{A} 1 \rightarrow \mathrm{B} 1 \rightarrow \mathrm{A} 2)$. The gravity difference is calculated by the following formula:

$\Delta g_{a b}=g_{r b_{1}}-\left[g_{r a_{1}}+\frac{g_{r a_{2}}-g_{r a_{1}}}{t_{a_{2}}-t_{a_{1}}}\left(t_{b_{1}}-t_{a_{1}}\right)\right]$

Here, $g_{r a_{1}}, g_{r a_{2}}, g_{r b_{1}}$ are the effective estimates of the gravity acceleration obtained for simple loop between A and B points. $\Delta g_{a b}$ is the difference of the gravity acceleration between $\mathrm{A}$ and B. $t_{a_{1}}, t_{b_{1}}, t_{a_{2}}$ are measured times corresponding to $\mathrm{A}_{1}, \mathrm{~B}_{1}$ and $\mathrm{A}_{2}$ points. The Bouguer anomaly and the Bouguer anomaly gradient were calculated based on the gravity and geodetic measurements results (Figure 3).

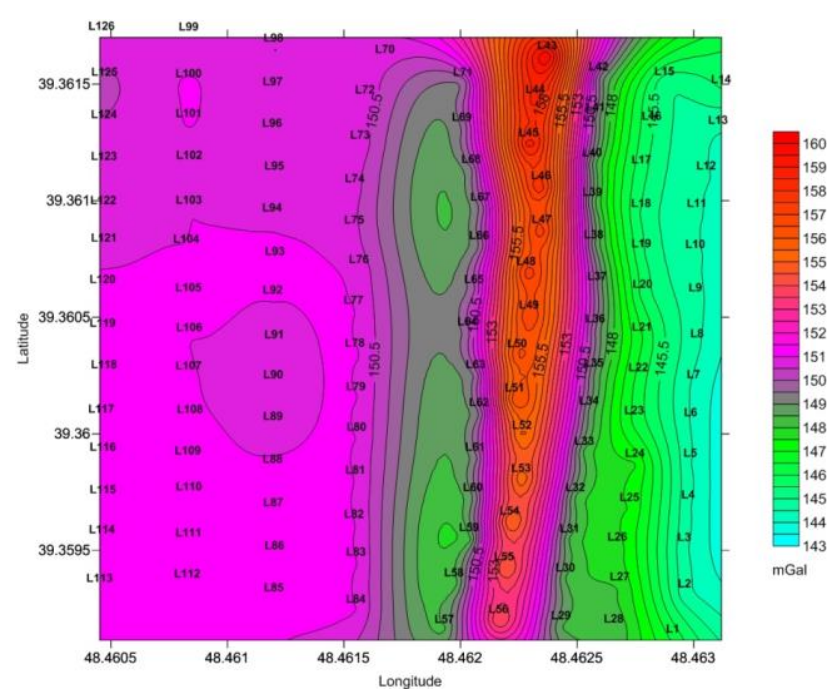

Figure 3. Bouguer anomaly map of Alkhantepe area (calculated using density of $2.67 \mathrm{~g} / \mathrm{cm}^{3}$ )

Multiple environments have been detected as a result of the combined analysis of the Bouguer 


\section{Geology and geophysics}

anomaly and Bouguer anomaly gradient characteristics obtained from high-precision gravity measurements carried out in the study area.

As seen from the Bouguer Anomaly Map (Figure 3) for the Alkhantepe area, the Bouguer anomaly maximums have been observed throughout the L43L56 measuring points (48.462 to 48.4625 in length) in the eastern part of the study area, where the presence of this maximums stand out by difference from other environmental characteristics in the area.

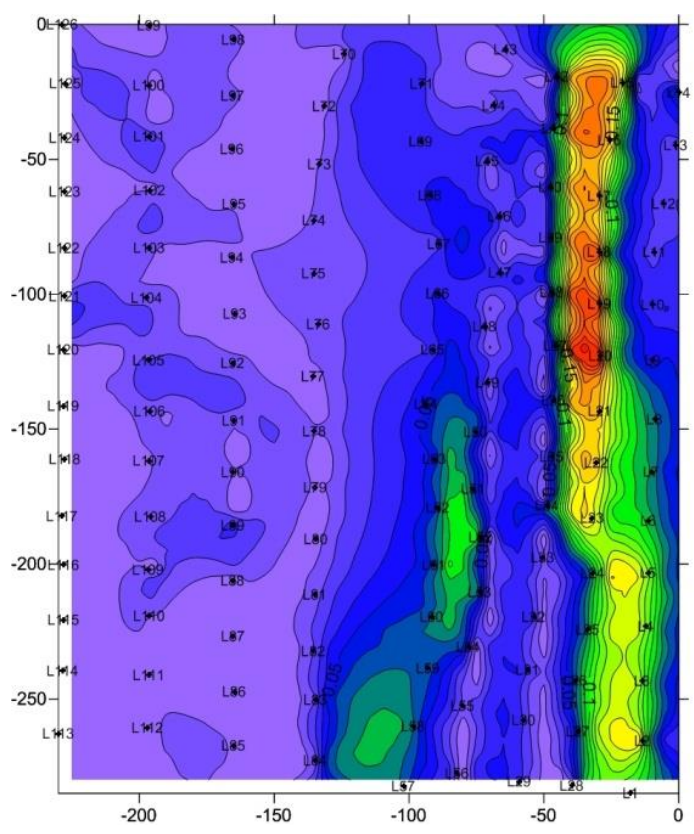

(a) backward direction method
This is clearly shown in the distribution map of the Bouguer anomaly gradient (Figure 4) calculated for the Alkhantepe area. The boundaries of the anomalous strip found in the distribution map of the Bouguer anomaly gradient are clearly stated. There are two anomalous boundaries in the distribution map of the gradients of the gravitational field. This shows the existence of walls. The results are consistent with the previous archeological researches carried out in Alkhantepe.

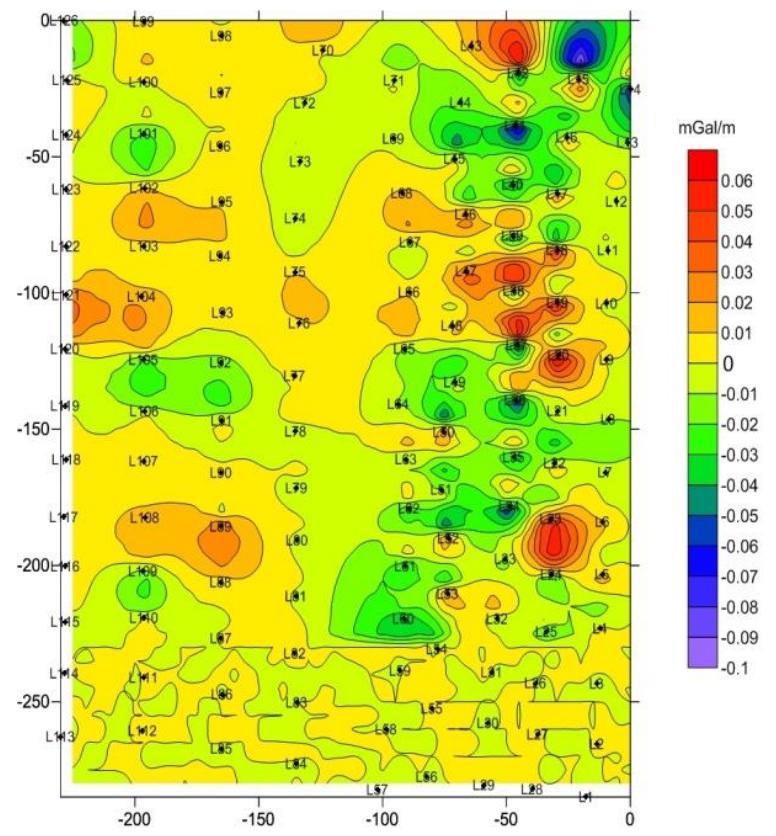

(b) central direction method

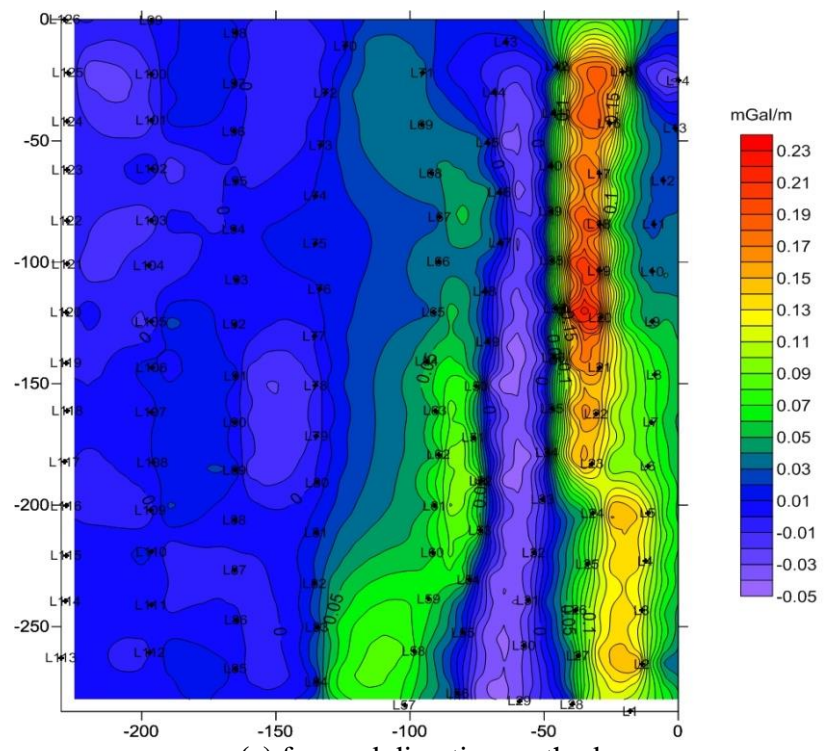

(c) forward direction method

Figure 4. Bouguer anomaly gradient distribution map of the Alkhantepe area 


\section{Radiometric measurements}

Radiometric studies in Alkhantepe were performed according to the "Temporary Methodological Guidelines for Pedestrian Gamma-Ray Surveys", "Guides for Radiometric prospecting and analysis" and "RTN 99/2009 Radiation safety norms" (Прудкина, Шашкин, 1984; Нормы радиационной безопасности, 2009; Temporary methodological guidelines..., 1986).

Based on the analysis of radiometric measurements in Alkhantepe archaeological area, maps of gamma-ray and radon gas concentration in underground air has been created (Aliyev Ch.S.). Natural background radiation of the research area and detection of anomalous zones were carried out with pedestrian gamma-ray surveys.

Dose-radiometer MKC-AT1125 is used to conduct the measurements. The background radiation measurements were carried out at 188 points, with a measurement step of about 20 meters by the pedestrian gamma-ray survey. Gamma-ray field of the area was mapped based on the obtained results (Figure 5).

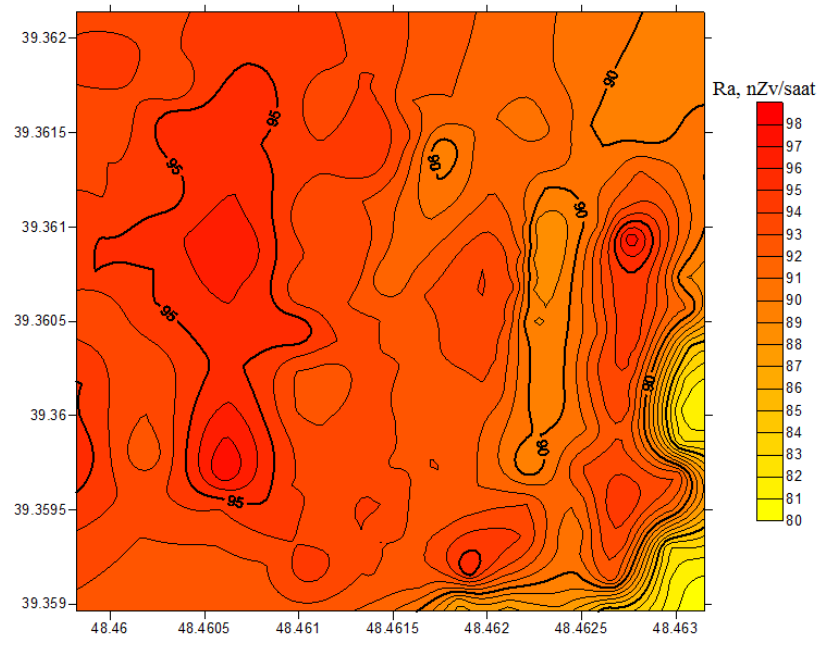

Figure 5. Gamma-ray distribution map of Alkhantepe research area (Aliyev Ch.S.)

The map of the gamma-ray field shows that high values of natural radioactivity $(95-98 \mathrm{nZv} / \mathrm{h})$ were observed in the south-western part, whereas north-eastern part of the research area is characterized by relatively low radioactivity $(85-90 \mathrm{nZv} / \mathrm{h})$. The background radiation values change between 82-98 nZv/hr.

Also the radon gas concentration of underground air was determined at 9 sites of the study area. Here, the radon gas concentration has been estimated to be about $168-1190 \mathrm{Bk} / \mathrm{m}^{3}$. Based on these results the map of radon gas content of the underground air has been generated for the research area (Figure 6).

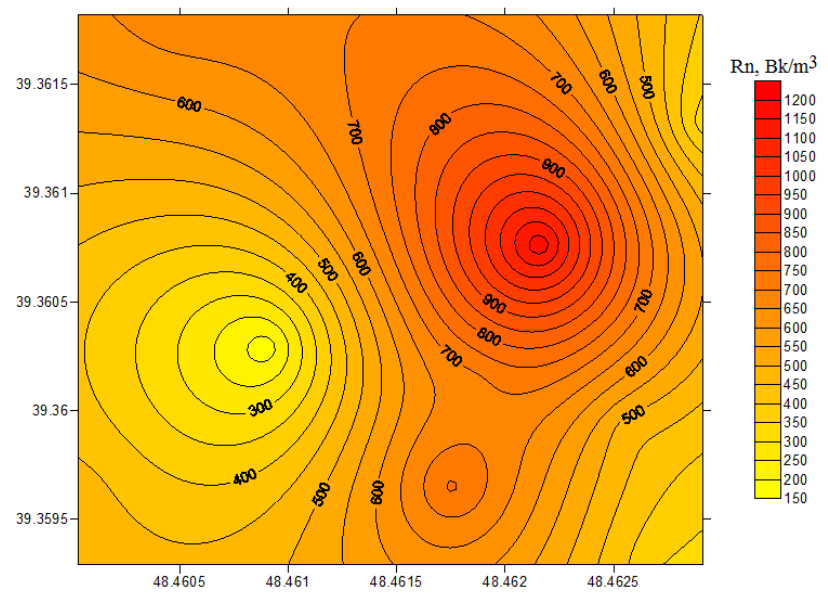

Figure 6. Map of radon gas content in underground air in Alkhantepe research area

According to the map shown in Figure 6 it appears that relatively high values of radon gas in the underground air (900-1200 $\mathrm{Bk} \mathrm{m}^{3}$ ) are found in the north-eastern part of the area and low concentration $\left(150-400 \mathrm{Bk} / \mathrm{m}^{3}\right)$ belongs to the south-western part of the area.

Analysis shows that cross-border of the high and low values may be considered as prospective for archaeological investigations. The presence of anomalous boundary in the distribution map of the radon gas content is consistent with previous studies in Alkhantepe.

\section{Conclusions}

The first experience of use of near-surface geophysical methods in archeological researches in Azerbaijan (radiometric and gravimetric) can be developed in the future to continue the research in this direction. The following results have been obtained during archeo-geophysical studies:

- the historical archeological scene of the research area is described;

- the possibility of applying of preventive geophysical methods in the complex study of archaeological monuments has been identified and the methodology of modified methods has been developed considering the characteristics of the area;

- the three-dimensional space and time model of the archeological site (Alkhantepe) with different physical parameters has been compiled;

- the sensitivity of the used archeo-geophysical methods to detect different types of objects was assessed and the reliability of the obtained results was tested on Alkhantepe monument. 


\section{REFERENCES}

Akhundov T.I. The South Caucasus on the threshold of the metal age. Context and connection: essays on the archaeology of the ancient Near East in honour of Antonio Sagona (Orientalia Lovaniensia Analecta). Peeters Publishers. Hardcover, 2018, pp. 49-77.

Akhundov T.İ. 20 days in Astara. Baku, 2009, 112 p. (in Azerbaijani).

Akhundov T I. Alkhantepe - an early bronze age settlement in Azerbaijan. Transactions of the Institute of the history of material culture, № 10, St.-Petersburg, 2014, pp. 78-92 (in Russian).

Clark A. Seeing beneath the soil. Prospecting methods in archaeology. ISBN 0-415-21440-8. B.T.Batsford Ltd. London, 1990, $196 \mathrm{p}$.

Jafarov A. Preliminary results of Paleolithic archeological expeditions. Archeological researches in Azerbaijan, 2001. Baku, 2002, pp. 25-28 (in Azerbaijani).

Makhmudov F. Culture of southeastern Azerbaijan in the Bronze Age and early Iron Age. Nafta-Press. Baku, 2008, 216 p. (in Russian).

Martynov A.I., Sher Ya.A. Geophysical methods in architecturalarchaeological researches. Research problems of architectural monuments. Moscow, 1990, pp. 102-113 (in Russian).

Mirzazadeh A.A. Mughan material-cultural monuments. Nargiz. Baku, 2016, 160 p. (in Azerbaijani).

Prudkina M.I., Shashkin V.L. Handbook of radiometric survey and radiometric analysis. Energoatomizdat. Moscow, 1984, 168 p. (in Russian).

Radiation safety norms. SanPiN 2.6.1.2523-09. RTN 99/2009 FCH and E. Moscow, 2009, 106 p. (in Russian).

Temporary methodological guidelines for pedestrian gammasurvey in radiation study of urbanized areas. $1986,17 \mathrm{p}$. (in Russian).

\section{ЛИТЕРАТУРА}

Akhundov T.I. The South Caucasus on the threshold of the metal age. Context and connection: essays on the archaeology of the ancient Near East in honour of Antonio Sagona (Orientalia Lovaniensia Analecta). Peeters publishers. Hardcover, 2018, pp. 49-77.

Clark A. Seeing beneath the soil. Prospecting methods in archaeology. ISBN 0-415-21440-8. B.T.Batsford Ltd. London, $1990,196 \mathrm{c}$.

Ахундов Т.И. Алхантепе - поселение начала эпохи бронзы в Азербайджане. Записки Института истории материальной культуры, № 10, С.-Петербург, 2014, с. 78-92.

Мартынов А.И., Шер Я.А. Геофизические методы в архитектурно-археологических исследованиях. Вопросы исследования памятников архитектуры, Москва, 1990, c. $102-113$.

Махмудов Ф. Культура юго-восточного Азербайджана в эпоху бронзы и раннего железа. Nafta-Press. Баку, 2008, $216 \mathrm{c}$.

Временные методические указания по пешеходной гаммасъемке при изучении радиационной обстановки городских территорий. 1986, 17 с.

Прудкина М.И., Шашкин В.Л. Справочник по радиометрической разведке и радиометрическому анализу. Энергоатомиздат. Москва, 1984, 168 с

СанПиН 2.6.1.2523-09. Нормы радиационной безопасности (НРБ 99/2009). ФЦГиЭ. Москва, 2009, 106 с.

Axundov T.I. Astarada 20 gün. Elm. Bakı, 2009, 112 s.

Cəfərov Ә. Paleolit arxeoloji ekspedisiyanın apardığ1 tədqiqatların ilkin nəticələri. Azərbaycanda arxeoloji tədqiqatlar, 2001. Bak1, 2002. s. 25-28.

Mirzəzadə Ә. Muğan, maddi-mədəniyyət abidələri. Nərgiz. Bak1, 2016, $160 \mathrm{~s}$.

\title{
РЕЗУЛЬТАТЫ ПРИМЕНЕНИЯ АРХЕОГЕОФИЗИЧЕСКИХ МЕТОДОВ НА ТЕРРИТОРИИ АРХЕОЛОГИЧЕСКОГО ПАМЯТНИКА АЛХАНТЕПЕ (АЗЕРБАЙДЖАН)
}

\author{
Сафаров Р.Т. ${ }^{1}$, Ахундов Т.И. ${ }^{2}$, Заманова А.Г. ${ }^{1}$, Алиев Ч.С. ${ }^{1}$, \\ Шарифова А.Т. ${ }^{,}$, Абдуллаев А.Н.ㄹ, Багирли Р.Дж. ${ }^{1}$ \\ ${ }^{1}$ Институт геологии и геофизики НАНА \\ AZ1143, г.Баку, просп. Г.Джавида, 119: rafiqsafarov@gmail.com \\ ${ }^{2}$ Институт археологии и этнографии НАНА \\ AZ1073, г.Баку, просп. Г.Джавида, 115: rafiqsafarov@gmail.com
}

Резюме. Изучение археологических объектов в районе нахождения нефте- и газопроводов, промышленных зданий и нефтяных терминалов очень актуально для Азербайджана. Применение геофизических методов основано на предварительном выявлении и исследовании археологических объектов, которые могут быть повреждены при возможном строительстве нефте- и газопроводов, разработке нефтегазовых месторождений, а также проведении каких-либо строительных работ. Использование этих методов в нашей стране позволяет археологам расширить возможности поиска археологических памятников, бережно отнестись к таковым существующим и предложить возможные корректировки на стадии планирования работ, а также принять превентивные меры.

Ряд геофизических методов был опробован в археологической зоне Алхантепе в целях разработки методов малоглубинной геофизики для обнаружения и первоначального исследования археологических памятников. Особое внимание было обращено на чувствительность археогеофизических методов, использованных для обнаружения различных типов объектов, а надежность результатов была проверена на археологическом памятнике Алхантепе. Были составлены трехмерные пространственные и временные модели археологических объектов. Для определения рельефа местности применялось высокоточное нивелирование, а для выявления возможных археологических объектов (полостей, трещин и т.д.) - высокоточные измерения гравитационного поля, фон естественной радиоактивности и аномальные зоны были установлены методом пешеходной гамма-съемки.

Ключевые слова: археогеофизические методы, Алхантепе, профилактическая археология, гамма-съемка 


\author{
ARXEOGEOFIZIKI ÜSULLARIN ALXANTəPЭ ARXEOLOJI ABIDəSI כRAZISINDЭ \\ TəTBIQQININ NOTICOLӘRI (AZəRBAYCAN) \\ Səfərov R.T. ${ }^{1}$, Axundov T.I. ${ }^{2}$, Zamanova A.H. ${ }^{1}$, Oliyev Ç.S. ${ }^{1}$, Şərifova A.T. ${ }^{1}$, Abdullayev A.N. ${ }^{2}$, Bağırlı R.C. ${ }^{1}$ \\ ${ }^{1}$ AMEA Geologiya va Geofizika Institutu \\ AZ1143, Bakl şəh., H.Cavid prosp., 119A: rafiqsafarov@ gmail.com \\ ${ }^{2}$ AMEA Arxeologiya va Etnoqrafiya İnstitutu \\ AZ1073, Bakı şəh., H.Cavid prosp., 115: tufan_akhundov@mail.ru
}

xülasə. Arxeoloji abidələrin aşkarlanması və ilkin tədqiqində kiçik dərinliklər geofizikasının tətbiqi metodunun və texnologiyasının hazırlanması məqsədilə Azərbaycan ərazisinin Alxantəpə arxeoloji zonasında bir sira geofiziki tədqiqatlar sinaqdan keçirilmişdir. İstifadə edilən arxeogeofiziki üsulların müxtəlif tipli obyektlərin müəyyən edilməsində həssaslığı nəzərə alınmış və nəticələrin etibarlılığı Alxantəpə arxeoloji abidəsi üzərində yoxlanılaraq, obyektin üçölçülü məkan və zaman modelləri tərtib edilmışdir. Tədqiqat ərazisində relyef xüsusiyyətlərinin öyrənilməsi üçün yüksək dəqiqlikli nivelirləmə, ehtimal olunan arxeoloji obyektlərin (boşluqlar, qırılmalar və s.) aşkarlanması məqsədilə yüksək dəqiqlikli qravitasiya sahə ölçmələri, ərazinin təbii radiasiya fonunun təyini və anomal zonaların aşkar edilməsində piyada qammaplanalma işləri həyata keçirilmişdir. Bu üsulların ölkəmizdə tətbiqi arxeoloqların axtarış imkanlarını genişləndirə bilər, digər tərəfdən - sənaye işlərinin planlaşdırılması (neft-qaz kəmərlərinin çəkilisi, neft-qaz terminallarının və neft quyularının yerlərinin seçilməsi və s.) mərhələsində ərazidə mövcud olan arxeoloji abidələri nəzərə almağa, layihələrə lazım olan düzəlişləri verməyə və preventiv tədbirlər görməyə imkan verər.

Açar sözlor: Arxeogeofiziki üsullar, Alxantəpə, preventiv arxeologiya, qammaplanalma 